\title{
SALMONELLA BIRKENHEAD : A NEW SALMONELLA TYPE CAUSING FOOD-POISONING IN MAN
}

BY

\author{
JOAN TAYLOR AND S. H. DOUGLAS \\ From the Salmonella Reference Laboratory, Colindale, London
}

(RECEIVED FOR PUblication, MAy 18, 1948)

During the six weeks from mid-July to the end of August, 1947, nine strains of a new Salmonella type were received from nine patients living in different parts of England, five of them in the Cambridge-Ipswich area.

\section{Clinical History}

Of the nine cases, seven gave a history typical of acute gastro-enteritis; one had enteritis only, and the last patient, who was investigated for reasons not relevant to the present paper, was a symptomless excretor of the organism. The patients with gastroenteritis complained of sudden onset of the disease with headache, abdominal pain, vomiting, and diarrhoea, and all showed some rise in temperature. The eighth case, a child, had similar symptoms except that she never vomited. Three patients were sufficiently ill to be admitted to hospital, one of them being described by her doctor as having symptoms suggestive of enteric fever. A fourth patient had been in hospital for six weeks with cardiac disease when he suddenly complained of diarrhoea ; this case terminated fatally after a two-day illness, but it is impossible to say how far the Salmonella infection may have contributed to the fatal issue. The findings are summarized in Table $\mathbf{I}$.
In all nine cases the organism (Salm. birkenhead, VI, VII ; $c \longleftrightarrow 1,6$ ) was isolated from the faeces. An attempt was made to determine whether any antibodies specific to the new Salmonella were present in the patient's serum on recovery. Sera

TABLE II

EXAMINATION OF SAMPLES OF BLOOD SERUM FROM PATIENTS

\begin{tabular}{l|c|c|c}
\hline \multirow{2}{*}{ Case } & \multicolumn{3}{|c}{ Agglutination titre to Salm. birkenhead } \\
\cline { 2 - 4 } & 0 & H (c) & H $(1,6)$ \\
\hline J.B. & $1: 25$ & - & - \\
M.B. & $1: 25$ & $1: 320$ & $1: 640$ \\
A.G. & $\overline{1: 50}$ & - & $1: 100$ \\
S. & $1: 50$ \\
\hline
\end{tabular}

All sera taken about four weeks after onset.

obtained from four cases gave the results shown in Table II. It will be seen that one case only' M.B., gave a high titre to the infecting organism. Such a finding is not uncommon in cases of infection

TABLE I

CLINICAL DATA AND DISTRIBUTION OF PATIENTS

\begin{tabular}{|c|c|c|c|c|c|c|}
\hline Case & $\begin{array}{c}\text { Age } \\
\text { (years) }\end{array}$ & Symptoms & $\begin{array}{c}\text { Duration of } \\
\text { illness }\end{array}$ & Domicile & & Date of onset \\
\hline $\begin{array}{l}\text { T.G. } \\
\text { H.G. } \\
\text { J.B. } \\
\text { J.L. } \\
\text { E.A. } \\
\text { M.B. } \\
\text { A.G. } \\
\text { S. } \\
\text { L. }\end{array}$ & $\begin{array}{c}46 \\
\text { Adult } \\
64 \\
2 \frac{1}{2} \\
35 \\
8 \\
3 \\
\text { Adult } \\
\text { Adult }\end{array}$ & $\begin{array}{l}\text { G.E. } \\
\text { G.E. } \\
\text { E. } \\
\text { G.E. } \\
\text { G.E. } \\
\text { G.E. } \\
\text { G.E. } \\
\text { G.E. }\end{array}$ & $\begin{array}{l}2 \text { days (fatal) } \\
27 \text { days } \\
7 \text { days } \\
15 \text { days }+ \\
7 \text { days } \\
9 \text { days } \\
7 \text { days } \\
7 \text { days }+.\end{array}$ & $\begin{array}{l}\text { London, Middx. } \\
\text { Blunham, Beds. } \\
\text { Birkenhead, Lancs. } \\
\text { Ipswich, Suffolk } \\
\text { Blunham, Beds. } \\
\text { Soham, Cambs. } \\
\text { Ipswich, Suffolk } \\
\text { Swindon, Wilts. } \\
\text { Newquay, Cornwall : }\end{array}$ & $\begin{array}{l}\ldots \\
\cdots \\
\cdots \\
\cdots \\
\cdots \\
\cdots \\
\cdots\end{array}$ & $\begin{array}{c}18.7 .47 \\
15.8 .47 \\
2.8 .47 \\
18.8 .47 \\
11.8 .47 \\
25.8 .47 \\
29.8 .47 \\
\text { end of Aug. } 47 \\
25.8 .47\end{array}$ \\
\hline
\end{tabular}

G.E. $=$ gastro-enteritis.

E. $=$ enteritis.

- $=$ no symptoms.

$+=$ patient not recovered when last seen. 
with members of the Salmonella group, in which a rise in antibody titre is much more variable than in enteric infection.

\section{Epidemiology}

Since all the nine cases described occurred during a six-week period, it was thought that some article of diet, such as a new type of food, might be responsible for this infection. Home visits were paid early in October, 1947, to the five persons in the Cambridge-Suffolk area. Inquiries were made into any unusual food eaten by the patients, into the local sources of food, into visits by patients to other places, and into visitors to the household during the three weeks before onset. No lead was obtained to suggest that further investigation would determine the source of infection. In one instance (A.G.), there was another case of gastro-enteritis in the household which preceded the case described (A.G.) by thirty hours ; this patient-a child-was not investigated.

\section{Bacteriology}

On MacConkey agar the Gram-negative motile bacillus isolated from the faeces of the cases described gave typical Salmonella colonies about $3 \mathrm{~mm}$. in diameter, round, with slightly crenated edge and glistening surface. The biochemical reactions were as follows: glucose, maltose, mannitol, dulcitol, sorbitol, rhamnose, xylose, and trehalose were fermented with the production of acid and gas in twenty-four hours, and arabinose in three days. Lactose, saccharose, salicin, adonitol, dextrin, and inositol were not fermented within three weeks. Gelatin was not liquefied, indole was not produced, and urea was not broken down. The Voges-Proskauer test was negative, methyl red test positive, hydrogen sulphide was produced in lead acetate agar, and the citrate utilization test was positive.

All nine strains gave identical serological reactions in that they were agglutinated to titre by Salm. oranienburg "O" serum. Reciprocal absorption tests by a heterologous strain removed all the homologous agglutinins. Thus the somatic antigenic complex is VI, VII. Of the nine strains, five were agglutinated to titre by $\mathrm{Salm}$. paratyphi $C$ "H" (c) serum, two to titre by Salm. anatum " $H$ " $(1,6)$ serum, and two to titre by both these sera. On growing the five strains in " $H$ " (c) phase in sloppy agar containing antiserum Salm. paratyphi $C$ " $H$ " (c) a second phase " $H$ " $(1,6)$ was isolated. Similarly on growing the two strains in " $H$ " $(1,6)$ phase in sloppy agar containing Salm. newport var. puerto rico " $H$ " $(1,2,3)$ serum, the first phase "H" (c) was isolated. Reciprocal absorption of Salm. paratyphi $C$ " $\mathrm{H}$ " (c) serum with the first phase of the new organism and a serum made against the new organism with Salm. paratyphi $C$ " $\mathrm{H}$ " (c) completely removed all the homologous agglutinins. Similarly reciprocal absorption tests using Salm. anatum " $\mathrm{H}$ " $(1,6)$ serum and an antiserum to the new strain proved these two phases to be identical. The flagellar antigens are therefore represented as $\mathrm{c} \longleftrightarrow 1,6$.

\section{Discussion}

The main interest in this new organism, Salm birkenhead (VI, VII ; $\mathrm{c} \longleftrightarrow 1,6$ ) lies in its close serological relationship to Salm. paratyphi C (VI, VII [Vi] ; c 1 1,5), Salm. cholerae-suis (VI, VII ; $\mathrm{c} \longleftrightarrow 1,5)$ and Salm. cholerae-suis var. kunzendorf (VI, VII ; $\mathrm{c} \longleftrightarrow 1,5$ ).

Salm. paratyphi $C$ may contain the $\mathrm{Vi}$ antigen found in many strains of Salm. typhi and Salm. ballerup; this antigen was absent from all nine strains of Salm. birkenhead, so in this respect the somatic complex differed from many but not all strains of Salm. paratyphi C. Salm. cholerae-suis and the kunzendorf variety both have the same somatic complex as Salm. birkenhead. It is well known that the flagellar antigen c can be obtained from the kunzendorf variety of Salm. choleraesuis (Gard, 1937; Bruner and Edwards, 1939); therefore serologically the only constant difference between Salm. paratyphi C, Salm. cholerae-suis, Salm. cholerae-suis var. kunzendorf, and Salm. birkenhead is that the second phase of the first three is 1,5 , of the last 1,6 .

The diagnostic biochemical reactions of Salm. paratyphi $C$, Salm. cholerae-suis, the kunzendorf variety, and Salm. birkenhead are given in Table III. From this it will be seen that the reactions of Salm. paratyphi $C$ and Salm. birkenhead are very similar.

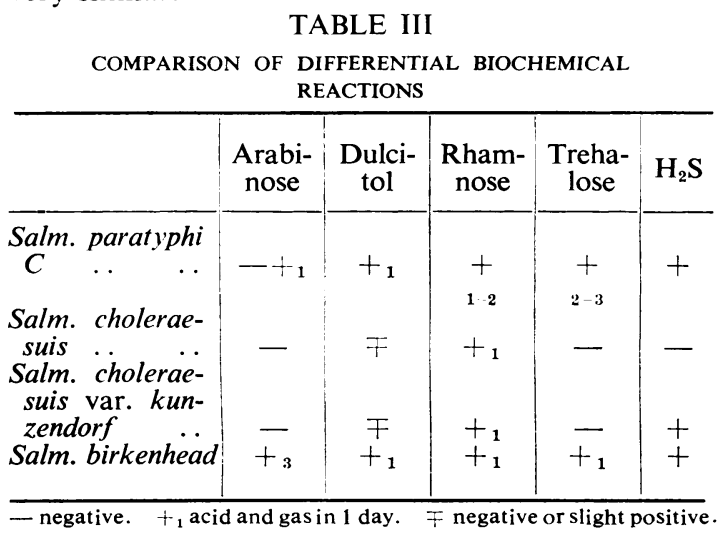


In spite of the close relationship between the four organisms discussed, the clinical picture is very different. Salm. paratyphi $C$ infection normally produces a serious illness, usually with continued fever. Complications of a septic type are not uncommon sequelae (Topley and Wilson, 1946), and two fatal cases of meningitis due to this organism have been described (Beattie and others, 1946).

Salm. cholerae-suis and the kunzendorf variety also cause serious disease. Harvey (1937) states that in sporadic cases in America the case-fatality rate in patients under 25 years of age is 19 per cent, in patients over 25 years of age 58 per cent. In his review of the literature describing epidemics due to this organism, he finds only five fatal cases among the 1,425 mentioned. Patients not uncommonly have sequelae such as pulmonary, bone, and joint infections, and endocarditis. He also describes four fatal cases of meningitis. In this country there have been few cases of this infection ; twelve were studied by Scott (Reports 1923 to 1939). During this period there were in addition four examples of generalized infection (Nabarro and others, 1929, two cases; Boycott and McNee, 1936, one case ; Guthrie, 1941, one case). .In this laboratory seven strains were studied between 1940 and 1947 ; two of these caused fatal septicaemia (Schwabacher and others, 1943): of the remaining five, three were isolated from blood cultures, two from faeces: all five patients recovered.

Salm. birkenhead caused clinical disease typical of ordinary food-poisoning, and though some cases were serious enough to be admitted to hospital, none could be described as being dangerously ill, except the one fatal case where death was attributed to primary cardiac disease. After a six- month interval no patient is known to have suffered from sequelae. From this review it seems probable that though Salm. paratyphi C, Salm. cholerae-suis, the kunzendorf variety, and Salm. birkenhead are very similar in their biochemical and serological reactions, yet the type of clinical disease produced in man may be very different.

\section{Summary}

1. A new Salmonella type, Salm. birkenhead, with the antigenic structure VI, VII ; $c \longleftrightarrow 1,6$ has been described. The Vi antigen was not detected in any of the strains.

2. This organism was isolated from the faeces of eight cases of food-poisoning and one symptomless carrier.

3. The difference in antigenic structure and clinical disease caused by Salm. birkenhead and the closely related organisms Salm. paratyphi C, Salm. cholerae-suis and Salm. cholerae-suis var. kunzendorf, are discussed.

We wish to thank the many bacteriologists for sending cultures for identification, and Dr. A. M. McFarlan, who so kindly carried out the epidemiological investigation in the eastern region.

\section{REFERENCES}

Beattie, C. P., Lawy, H., and Taylor, Joan (1946). Mon. Bull. Min. Hlth., Lond., 5 , 184.

Boycott, J., and McNee, J. W. (1936). Lancet, 2, 741.

Bruner, D. W., and Edwards, P. R. (1939). Amer. J. Hyg., $30,75$.

Gard, S. (1937). Z. Hyg. Infekt. Kr., 120, 59.

Guthrie, K. J. (1941). Arch. Dis. Childh, 16, 269

Harvey, A. M. (1937). Arch. intern. Med., 59, 118.

Nabarro, D., White, P. Bruce, Dyke, S. C., and Scott, W. M. (1929). Lancet, $2,868$.

Reports (1923-38). Ann. Rep. Min. Hlth., London.

Schwabacher, Herta, Taylor, Joan, and Gleeson White, M. H. (1943). Brit. med. J., 2, 358.

Topley, W. W. C., and Wilson, G.S. Revised by Wilson, G. S., and Miles, A. A. (1946). "Principles of Bacteriology and Immunity." London. 